\title{
If Machines Want To Dream... Adam Wiśniewski-Snerg on the Ethical Consequences of There Being No Substantial Distinction Between Humans and Robots
}

\author{
Artur Jocz \\ (Adam Mickiewicz University, Poznań; artur.jocz@amu.edu.pl ) \\ ORCID: 0000-0001-8934-1167
}

If we search through Polish literature for an archetypal cyborg, droid, drone, or perhaps just a robot, we cannot overlook the artistic visions of Bruno Schulz (18921942) which appeared in the Traktat o manekinach albo Wtóra Księga Rodzaju [A Treatise on Mannequins, or the Second Book of Genesis] (Schulz 1989a) and Traktat o Manekinach. Ciag dalszy [A Treaty on Mannequins. Continued] (Schulz 1989b). It was in these texts that Schulz created an unusual, and above all ontologically and ethically intriguing being: a sentient, suffering mannequin (Jocz 2003; 2006; 2016). Thanks to its self-awareness, this "dummy" (Schulz 1989b, 38) discovers all the limitations associated with having a material existence. It experiences the sense of being disposable, the finiteness of its own existence. However, the mannequin's most oppressive experience is the struggle with the existential shape imposed on it by a human being, from which there is no escape. A human simply created the mannequin according to his will, and for a specific purpose known only to himself. In order to express the nature of this material enslavement, Schulz wrote:

Can you imagine the pain, the dull imprisoned suffering, hewn into the matter of that dummy which does not know why it must be what it is, why it must remain in that forcibly imposed form which is no more than a parody? (Schulz 1989b, cf. $)^{1}$.

By means of this poignant and pithy metaphor, Schulz gave expression to a sentient being's immanent rejection of externally imposed limitations. They are all the more difficult to accept because their ontological form results from the completely unrestricted, demiurgical fantasy of the creator. ${ }^{2}$ The manifestation of the creator's free will leads to

1 Trans. by C. Wieniewska, The Street of Crocodiles (1995), retrieved from https://openlibrary. org/books/OL22539680M/The_street_of_crocodiles

2 The term used by Jakub (the main heresiarch of Schulz's world) was an inspiration for Gnostic interpretations of Schulz's literary output. On the subject of the phenomenon of gnosis, Gnosticism and their presence in Polish literature, see e.g. Myszor (1971; 1977), Jonas (1994), Prokopiuk (1998; 1999; 
the total enslavement of the created being.

But should we compare Schulz's vision with the world presented by Adam WiśniewskiSnerg (1937-1995) in Robot (1973)? Is there any value in treating Schulz's mannequin as prefiguring of some of the themes that emerge in the novels of later science fiction writers? It seems that such a hypothesis can be boldly accepted. Firstly, because in Według totra [According to the Thief], another novel by Wiśniewski-Snerg, there is a complex plot involving sentient mannequins (Jocz 2017, 57-68). However, the comparison in Robot is more pertinent, since the robot that becomes conscious is explicitly described as a mannequin. The association appears in the following passage:

When, through the millennia, people observed their outer form and deluded themselves that what made them human was their fingers, ears, eyes, upright posture, and - above all - their brain, many asked themselves what would happen in the inevitable future, when a mannequin, draped and stuffed with a synthetic body, would straighten up, move all its limbs efficiently, and, turning a head filled with an electronic brain to his constructor, would say in a very suggestive tone: "Human - that's exactly what I am!" (Wiśniewski-Snerg 1977, 241).

In the words quoted above one can sense a kind of depreciation of the mannequin's existence, in a manner that recalls Schulz's description. It is worth remembering that the author of The Cinnamon Shops assigned the mannequin to a separate, "lower sphere of existence" (Schulz 1989a, 34). Wiśniewski-Snerg achieved a similar effect by describing the mannequin as "stuffed with a synthetic body". At the same time, however, he noticed all the deficiencies inherent in the existing definitions of the human being and humanity. Of course, the issue here is identifying the phenomenon of being human with its phenotype. It is in this way that the difficulty in distinguishing between human existence and the existence of a mannequin-robot, which has with a similar phenotype, will become a real one.

Therefore, drawing attention to the ethical, philosophical consequences of this problem will be the main objective of these considerations. They will of course be conducted only with regard to the reality of the literary world created by Adam Wisniewski-Snerg in Robot. On the other hand, however, his artistic visions take on a completely different meaning in the light of contemporary work on the construction of artificial intelligence. They become a kind of "prevision" for them. Wisniewski-Snerg's artistic voice also resonates with the writings of other, often more famous artists who also attempted to explore the mystery of machines that became self-aware thanks to their human creators, but which also became independent of them. However, we should stress Wisniewski-Snerg's artistic independence from the work of Philip K. Dick (1928-1982) and Stanisław Lem (1921-2006), such as the former's Do Androids Dream of Electric Sheep? and the latter's Golem XIV. Although Dick's book was published in 1968, its translation did not appear in Poland until 1995; and the first part of Golem XIV was published in 1973. Therefore, Wisniewski-Snerg is one of the first writers to address the issue of artificial 
intelligence in Polish literature.

When entering the literary reality of Adam Wiśniewski-Snerg, the reader follows the spectacular process of the eponymous robot's creation and the subsequent unfolding of his fate. However, a detailed analysis of the novel's plot lies outside the scope of this article. Instead, the question of the disappearance of the ontological border between the human and the machine will be explored. Creating his own world, the writer puts special emphasis on the ambiguity of this border. Perhaps this is why the reader does not gain full information about the nature of the robot's creators, who call themselves "the Mechanism" (Wiśniewski-Snerg 1977, 9), until the end of the work; or about the robot's ultimate purpose. The enormity of the mystery surrounding this figure is revealed in the following passage of the novel:

- We brought you to life (...) so that you could have a part in the great mystery. You were born in a certain, well-defined range of our interior, where you were given a human form, a biological being - with all the numerous advantages and disadvantages that accompany this. You already have an eight-month period of painstaking learning behind you, in which, with the help of the devices known to you, you managed to master the general knowledge necessary for further learning. (...) You can be proud of yourself: you are human. You are human to the extent that we needed you to be, and to which we - less limited than you - were able to make you. You went through all the stages of accelerated development to finally undergo testing of the results. (...) You showed fear, and curiosity stronger than fear. Therefore, you have fulfilled the necessary prerequisite, which entitles you to demand the answer to the question of why you have achieved a level of material and spiritual organization equal to human beings. So, you will soon learn that you will never get the final answer, one that would not involve an infinite number of further questions. (...) To make you as similar as possible to the people among whom you have to act, we also gave you an imitation of free will. (...) From a subjective point of view, you will be able to move freely; our power over you will not weigh you down (...). Meanwhile, with the simultaneous occurrence of many emerging possibilities of action, the strongest desire will always prevail in you - that is, the desire through which we will express our will, and thus, obscured by other, less imposing necessities, our real command (Wiśniewski-Snerg 1977, 12-14).

Robot (BER-66) was therefore shaped in the deepest bowels of the Mechanism. But did he fully exist in the image and likeness of human beings? From the very beginning, he owes the fundamental truth about his existential status to a brutal initiation devoid of any gnostic charm, which is performed by an individual that is of the same kind as him, differing only in the serial number - BER-64. At the same time, BER-66 also realizes that, due to his very nature, he deserves only a small and limited fragment of knowledge, the entirety of which remains beyond the reach of even the Mechanism. It turns out, therefore, that this near-omnipotent producer serves other, higher beings. Thus, it should be assumed that the level of perfection in this hierarchy is determined by the range of knowledge that is possessed.

This is an appropriate time for addressing the main theme of Wiśniewski-Snerg's novel. It is no less than humanity meeting a civilization from the depths of the cosmos; one which surpasses human development. However, these creatures do not make any 
attempt at engaging in dialogue with the inhabitants of Earth. They simply cut out an entire city from the surface of the Earth, along with the nuclear shelter underneath it, and take it away in some unimaginable spacecraft. They are probably the Constructors of the Mechanism and thus are indirectly responsible for the work of BER-66, which they want to use as a resource for learning about human nature. The robot is supposed to be gathering information on the society which, at the moment of approaching threat from space, locked itself in the shelter and cut itself off from the surface of the city. So, it is a kind of attempt at natural research.

It is worth remembering, however, that the ontological foundations of WiśniewskiSnerg's novel are also a kind of archetype dressed in a contemporary literary costume. This archetype was formed in European culture, back in the period of Christian Gnosticism. This is evidenced by the teaching of the gnostic Valentinus on the nature of Sophia's sin of pride, who is one of the Aeons surrounding the Perfect Being. Valentinus claimed that Sophia's misdeed was based on the desire to have full knowledge - gnosis about the essence of the Perfect Being. Of course, it is difficult to speak unequivocally about the influence of Gnosticism on the works of Wiśniewski-Snerg, but the notion that this kind of thought is present in Polish Romantic and neo-Romantic literature is no longer controversial (Tomkowski 1983, 54-73; Fiećko 2012, 61-71; Jocz 2016, 153-162; Jocz 2009). Therefore, it is an element of the spiritual space of Polish culture. It is worth noting, however, that the author of Robot consistently and unequivocally deprived his literary heroes of any hope of gaining final knowledge - gnosis concerning the essence of the reality in which they found themselves. The eponymous robot must therefore accept his insignificance and limitations in the face of the power of darkness that shrouds his future. Or is it just a metaphor for the fate of every human being?

In order to answer this question without succumbing to truism, the Mechanism's imitative powers should be appreciated. The robot does not differ phenotypically from human beings and seems to be biologically identical with them. It also has typically human feelings, such as curiosity and fear. However, the Mechanism suggests that the humanity of BER-66 has been adapted to serve very clearly defined needs. His whole being is subordinated to the goal of acquiring information about the people around him. The robot is a perfect spy, because it automatically, or even involuntarily, passes knowledge gained about real human beings to the Mechanism. It is able to do this because it is equipped with only an "imitation of free will". This is a perfect camouflage which should help him in his relations with the people he spies on. However, the point was not to make the machine look like an ordinary human being, but rather to free BER- 66 from all ethical dilemmas. If he subjected his own actions involving people to moral evaluation, he would move closer to humanity. Meanwhile, the "imitation of free will" seeks to gently free the robot from the burden of ethical choices and the temptation of humanity. After all, it has been constructed in such a way that every strong desire is a manifestation of the will of the Mechanism. Of course, this mysterious ruler is alien to any human ethical system 
and does not treat the permanent control of BERa-66 as the unequivocal enslavement of another being.

Once again, there is an echo of the mannequins from Schulz's world, which were created "for one gesture, one word alone" (Schulz 1989a, 35). This is also the case with the robots of Wiśniewski-Snerg's novel, but its reality is much more literal and, unfortunately, it lacks the charming metaphors created by the Schulz. Is the robot determined by the Mechanism to be left with just the silent suffering that characterized Schulz's mannequins?

This is how Schulz and Wiśniewski-Snerg brought sharp focus to the quest for the ethical responsibility of the Demiurge/Constructors for the fate of the mannequin/robot. When bringing a sentient being to life, the creator should remember that the potential to instil emotions will influence the shape of the inner, quasi-psychic world of every robot. If a mannequin/robot equipped with an immanent emotional reality encounters its natural limitations, it will suffer in real life. In the case of Schulz's mannequins, these limitations were found to lie in their disposable bodies, and BER- 66 was painfully determined by the requirements of his imposed spying mission. With BER-66, however, this dictate of duty gave rise to moral dilemmas about the ethical dimension of his actions. Then, thanks to his developing humanity, he discovered his lack of honesty towards the people around him.

It turns out that the human potentials inscribed in its nature manifest themselves in the form of a rebellion against the power of the Constructors. It manages to escape from the bunker and get into the society of the city above. Perhaps, however, this is only one more manifestation of the will of the Mechanism, which has already assigned new tasks to the robot. On the other hand, however, BER-66's dream of freedom can be viewed as a clear proof of his humanity: machines can't dream, can they?

Translated from Polish by Stephen Dersley

\section{References}

Fiećko J. 2012. „Krasiński o gnozie. Nota o notatkach poety.” In: B. Sienkiewicz, M. Dobkowski, \& A. Jocz (Eds.), Gnoza, gnostycyzm, literatura (pp. 61-71). Kraków: Zakład Wydawniczy „NOMOS”.

Jocz A. 2003. „Bruno Schulz, czyli o gnostycznej pokusie literatury.” In: M. KitowskaŁysiak \& W. Panas (Eds.), W ułamkach zwierciadła... Bruno Schulz w 110 rocznice urodzin i 60 rocznicę śmierci (pp. 275-288). Lublin: Towarzystwo Naukowe KUL.

Jocz A. 2006. „Bruno Schulz, czyli o gnostycznej próbie uchwycenia fenomenu cierpienia." Przegląd Religioznawczy 1(219):47-58. 
Jocz A. 2016. „Gnostyczne poszukiwania polskich romantyków. Wybrane przykłady.” In:

A. Dziedzic, T. Herbich, S. Pieróg, \& P. Ziemski (Eds.), Romantyzmy polskie (pp. 153162). Warszawa: Fundacja Historii Filozofii Polskiej.

Jocz A. 2016. Gnostyczne światy Brunona Schulza. Poznań: Wydawnictwo Naukowe Wydziału Nauk Społecznych UAM.

Jocz A. 2017. „Popkulturowa recepcja chrześcijańskiej kategorii zła. Wybrane przykłady”” Przegląd Religioznawczy 1(263):57-68.

Jocz A. 2009. Przypadek „Osy rozbójniczej”. Rozważania o gnostycyzmie i neognozie w literaturze przełomu XI i XX wieku. Poznań: Wydawnictwo Naukowe UAM.

Jonas H. 1994. Religia gnozy, trans. M. Klimowicz. Kraków: Wydawnictwo PLATAN.

Myszor W. 1971. „Gnostycyzm - przegląd publikacji.” Studia Theologica Varsaviensia 1: 367-424.

Myszor W. 1977. „Gnostycyzm w tekstach z Nag-Hammadi.” Studia Antiquitatis Christianae 1(2):121-260.

Prokopiuk J. (Ed.) 1987. „Gnoza.” Literatura na Świecie 12 (197).

Prokopiuk J. 1998. Gnoza i gnostycyzm. Warszawa: Typograficzna Oficyna Wydawnicza FIRET \& Antykwariat DAIMONION.

Prokopiuk J. 1999. Labirynty herezji. Warszawa: Warszawskie Wydawnictwo Literackie MUZA.

Prokopiuk J. 2000. Ścieżki wtajemniczenia. Gnosis aeterna. Warszawa: tChu.

Przybył E. 2000. Oblicza gnozy. Kraków: Zakład Wydawniczy „NOMOS”.

Schulz B. 1989a. „Traktat o manekinach albo Wtóra Księga Rodzaju.” In: Opowiadania. Wybór esejów i listów, BN, Series I, No. 264 (pp. 33-37.). Wrocław - Warszawa Kraków - Gdańsk - Łódź: Zakład Narodowy im. Ossolińskich.

Schulz B. 1989b. „Traktat o manekinach. Ciąg dalszy.” In: Opowiadania. Wybór esejów i listów... (pp. 37-40).

Sienkiewicz B., Dobkowski M., \& Jocz A. (Eds.). 2012. Gnoza, gnostycyzm, literatura. Kraków: Zakład Wydawniczy „NOMOS”.

Tomkowski J. 1983. „Świat gnozy Tadeusza Micińskiego.” In: T. Bujnicki \& J. Illg (Eds.), Młoda Polska. Legendy i światopoglądy (pp. 54-73). Katowice: Uniwersytet Śląski. Wiśniewski-Snerg A. 1977. Robot. Kraków: Wydawnictwo Literackie. 


\title{
Artur Jocz (Poznań)
}

\section{If Machines Want to Dream... Adam Wiśniewski-Snerg on Ethical Consequences of There Being No Substantial Distinction between Humans and Robots ${ }^{3}$}

\begin{abstract}
Adam Wiśniewski-Snerg (1937-1995) was a Polish science fiction writer. In his novel Robot (1973), he made an attempt at a literary visualization of a machine acquiring human identity. In this article I would like to follow the ethical consequences of such situations in created literary worlds. It is worth remembering, however, that these artistic worlds often serve to test non-literary reality. In his novel, Wiśniewski-Snerg also dealt with the problem of human feelings (e.g. moral dilemmas) in a thinking machine, which is formed in the image and likeness of a human being. Such literary reflection is valuable, partly because it enters into an interesting dialogue with the work of Bruno Schulz (18921942), one of the most important Polish writers of the 20th century. It is also one of the first attempts in Polish literature to address the issue of sentient machines, and is a kind of preview of contemporary dilemmas connected with the work on the creation of artificial intelligence. An example of such a dilemma is the issue of the sentient machine's perception of the tasks imposed on it by the human-constructor. Perhaps it will start to experience them as a kind of unethical oppression. In Wiśniewski-Snerg's writing this problem of is, of course, expressed in a metaphorical way.
\end{abstract}

Keywords: robot; mannequin; gnosis; Gnosticism; Mechanism; humanity; Adam Wiśniewski-Snerg; Polish science fiction of the 1970s; Bruno Schulz.

Ethics in Progress (ISSN 2084-9257). Vol. 10 (2019). No. 2, Art. \#5, pp. 45-51.

Creative Commons BY-SA 4.0

DOI:10.14746/eip.2019.2.5

3 The article was translated by Stephen Dersley, with the translation supported by the grant 261/ WCN/2019/1 "Wsparcie dla Czasopism Naukowych" (2019-2020) in order to promote original Polish research worldwide. 